\title{
肩関節周囲炎患者における胸郭可動性と 肩関節機能との関連
}

\author{
Relationship between Thoracic Mobility and Shoulder Joint Function \\ in Patients with Frozen Shoulder
}

\author{
小坂 健二 ${ }^{1)}$ 神澤 佑哉 ${ }^{1)}$ \\ KenJi KOSAKA, RPT ${ }^{1)}$, YuYA KAMIZAWA, RPT ${ }^{1)}$ \\ ${ }^{1)}$ Department of Rehabilitation, Kawachi General Hospital: 1-31 Yokomakura, Higashiosaka-shi, Osaka 578-0954, Japan \\ TEL+81 72-965-0731 E-mail: ksk19772000@yahoo.co.jp
}

Rigakuryoho Kagaku 37(1): 111-115, 2022. Submitted Sep. 16, 2021. Accepted Oct. 25, 2021.

\begin{abstract}
Purpose] The relationship between thoracic mobility and shoulder joint function in patients with frozen shoulder was examined using the precordial flexibility test and chest expansion measurement. [Participants and Methods] The participants were 22 individuals diagnosed with frozen shoulder. The correlations between their precordial flexibility test/chest expansion measurement results and the following parameters were investigated during the initial physical therapy: scores based on the Japanese Orthopaedic Association Criteria for the Evaluation of Treatment Outcomes in Diseases of the Shoulder Joint (JOA scores), at-rest and at-movement Visual Analogue Scale (VAS) scores, and the shoulder range of motion (flexion, external rotation with the arm at side, and internal rotation). [Results] Both precordial flexibility test and chest expansion measurement results were correlated with at-rest VAS scores. [Conclusion] Thoracic mobility and rest shoulder pain may be associated in patients with frozen shoulder.

Key words: frozen shoulder, thorax flexibility, shoulder joint function
\end{abstract}

要旨：〔目的〕前胸部柔軟性テストおよび胸郭拡張差を用いて肩関節周囲炎患者における, 胸郭可動性と肩関節機能 との関連を検討した。〔対象と方法】対象は肩関節周囲炎と診断された 22 名とした。理学療法初診時に前胸部柔軟 性テストおよび胸郭拡張差と, 日本整形外科学会肩関節疾患治療成績判定基準（JOA スコア），安静時扔よび運動時 Visual Analogue Scale (VAS), 肩関節可動域（屈曲，下垂位外旋，内旋）との相関関係を調査した。〔結果〕前胸部 柔軟性テストおよび胸郭拡張差と安静時 VAS にそれぞれ相関が認められた。〔結語〕肩関節周囲炎患者では胸郭可動 性と肩安静時痛が関連している可能性が示唆された。

キーワード : 肩関節周囲炎, 胸郭柔軟性, 肩関節機能

\footnotetext{
1) 河内総合病院リハビリテーション部：大阪府東大阪市横枕 1-31（テ 578-0954）TEL 072-965-0731 


\section{I.はじめに}

肩関節周囲炎は肩の疼痛と運動制限を呈する疾患の総 称とされている1)。諸外国では肩関節周囲炎と「frozen shoulder (凍結肩)」および「adhesive capsulitis（癒着 性関節包炎)」は同義語として扱われており2)，本稿で も同義語として取り扱う。癒着性関節包炎は 40～70 歳 代に発症する症例が $80 \%$ 以上とされており 3,4$)$, 中高年 者に発症することが多い，また，肩関節可動域制限を有 している症例の $60 \%$ が肩関節周囲炎とされている5).

Zuckerman 5 6) は, 凍結肩の分類を一次性（原発性） と二次性に大別し，さらに二次性をintrinsic（肩関節に 原因のあるもの), extrinsic（肩関節以外の部位に原因 があるもの), systemic（全身性）の3つに分類しており， 発症原因は様々である。

肩関節周囲炎患者において胸郭可動性が低下している 症例を多く経験する。立原ら 7)は, 凍結肩症例において, 約 30\%は胸鎖関節, 胸胁関節, 約 $40 \%$ は胸椎, 肋椎関 節に機能異常をきたしていると報告しているが，胸郭機 能と肩関節機能との詳細な関係性については検討されて いない.また, Zuckermanら6)の凍結肩の分類の extrinsicに, 肩甲胸郭関節の異常が挙げられており, 肩 関節周囲炎と胸郭の機能異常に関連があることが予測さ れる。

関節を包括的に捉える理論である joint by joint theory では，関節はそれぞれ可動性と安定性のいずれかの機能 をもち，それが交互に配列されていると考えられてい る ${ }^{8)}$. この過程では, 可動性が必要とされる胸郭の可動 性が低下することで, 安定性が必要とされる肩関節に代 償が生じ, 結果として障害や疼痛を引き起こすことが推 察される。肩関節の運動には, 肩甲上腕関節のみではな く肩甲胸郭関節の果たす役割も大きく，肩関節の近隣関 節である胸郭の機能を評価することは, 臨床上では重要 であると考える。

胸郭可動性の評価については, 三次元解析装置や超音 波診断装置で測定する方法が報告されている 9,10$)$. しか し, これらの評価には高額な医療機器が必要であり, 簡 便に評価することは難しい. 簡便な胸郭可動性の評価法 として, 胸郭拡張差をテープメジャーで測定する方法が ある ${ }^{11)}$. 胸郭拡張差に関しては, 剣状突起高の拡張差 が他の部位と比較し最も可動性が高く, 胸郭全体の可動 域を反映するとされている11)。また, その他の胸郭可 動性の評価方法として前胸部柔軟性テスト（TrunkAcromion-Floor-Distance：以下, Tr-AFD テスト）があ る 12,13).

Tr-AFD テストは単関節の可動性評価ではなく, 胸椎 伸展や肩甲骨後傾, 内転, 胸郭の機能的変形など, 投球 動作において必要な可動性を評価するものとして考案さ れた ${ }^{12)}$ 。Tr-AFD テストはメジャーにて簡便に測定が可
能であり，臨床上でも有用なテストである，我々は，健 常者に対する Tr-AFD テストの信頼性について明らかに しており，良好な信頼性が得られている14)。

しかし，Tr-AFD テストは胸郭全体の可動性との関連 を記した報告はされておらず，前胸部の可動性だけでな く, 胸郭全体の可動性を反映しているかは疑問がある.

したがって，本研究の第一の目的は，Tr-AFD テスト と胸郭拡張差が関連しているかを検証することである. 第二の目的は, Tr-AFD テストおよび胸郭拡張差と肩関 節機能との関連を明らかにすることとした。

肩関節周囲炎患者において, 胸郭可動性と肩関節機能 との関連を明らかにすることにより，肩関節障害に対す る治療や予防における胸郭機能の重要性が示唆され, 具 体的なアプローチの検討につながると考える。

\section{II. 対象と方法}

\section{1. 対象}

対象は，筆頭著者所属施設において 2020 年 11 月か ら 2021 年 8 月まで, 肩関節周囲炎の診断を受けた 32 名とした。除外基準は，患側上肢に骨折や手術歴がある 者, 腱板断裂症状がある者（徒手筋力テストにて肩外転 が 5 未満, 肩外旋 5 未満, 肩内旋・外旋によるインピン ジメント症状の 3 つが揃っている者）15), 意思疎通が困 難な者, 中枢系疾患を有する者, 同意が得られなかった 者, データ欠損者とした。対象のうち除外基準に該当し た 10 名を除く 22 名（男性 8 名，女性 14 名，年齢 57.0 \pm 11.1 歳, 身長 $161.1 \pm 8.9 \mathrm{~cm}$ : 平均 \pm 標準偏差 $)$ を 分析対象とした。

本研究は, 河内総合病院倫理委員会にて承認を得て実 施した（承認番号：2020-002）。なお, 対象者には本研 究の目的や内容, 方法などを十分に説明し, 自由意志に て承諾を得た。

\section{2. 方法}

肩関節可動域は，肩関節屈曲，下垂位外旋，内旋を測 定した。屈曲, 下垂位外旋に関しては, 日本整形外科学 会および日本リハビリテーション医学会に準じ, 東大式 ゴニオメーターを用いて測定した。内旋可動域について は結帯動作にて評価し，第 7 頸椎棘突起と母指先端の指 椎間距離（C7-thumb distance：以下, C7-TD）をテープ メジャーにて測定した。測定姿勢は屈曲, 下垂位外旋, C7-TDともに端座位とした。

胸郭拡張差は安静端座位にて, 被検者の最大吸気と最 大呼気に拈ける, 剣状突起レベルの胸郭拡張差を, テー プメジャーを用いて $5 \mathrm{~mm}$ 単位で測定した。測定は 3 回 行い, 最大值を測定值とした ${ }^{11)}$.

Tr-AFD テストは, 被検者をベッド上側臥位とし, 枕 は頸部中間位となるように高さを調整した。両股関節・ 


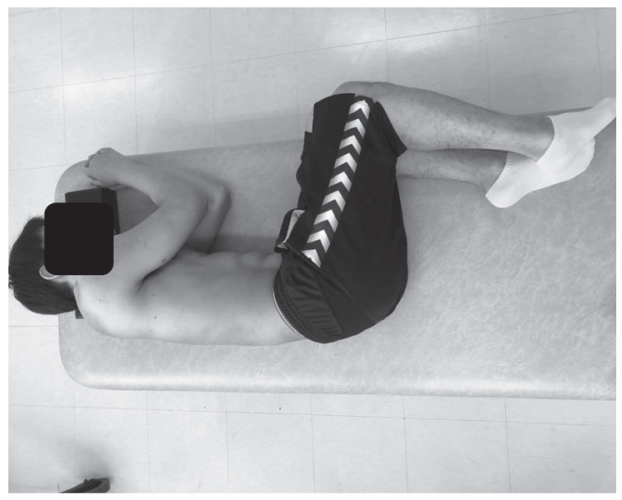

a

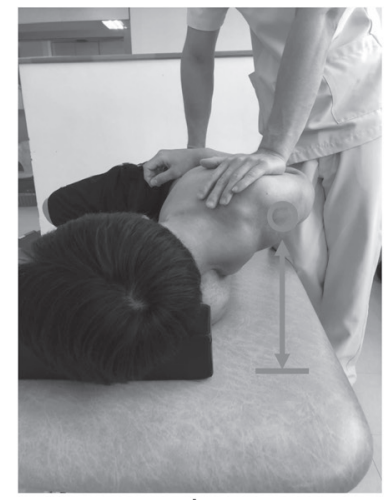

b

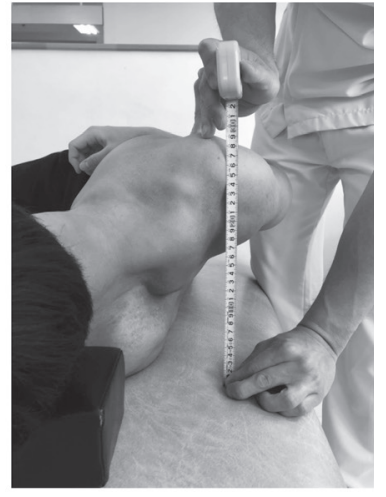

C

図 1 Tr-AFD (Trunk-Acromion-Floor-Distance) テストの測定方法

$\mathrm{a}$ : 開始肢位.

$\mathrm{b}$ ：検者は骨盤一腰椎を徒手にて固定した状態で, ベッド非接触側肩甲带を背側へ痛みのない範囲で最 大限に捻転させる.

$\mathrm{c}$ ：肩峰後角とベッドとの距離を被検者の背側からスチールメジャーにて測定.

膝関節を屈曲 $90^{\circ}$ 位，体幹は中間位を保持するよう設定 した，検者は骨盤一腰椎を徒手にて固定した状態で， ベッド非接触側肩甲带を背側へ痛みのない範囲で最大限 に捻転させ，肩峰後角とベッドとの距離を被検者の背側 からスチールメジャーにて $1 \mathrm{~cm}$ 単位で測定した ${ }^{14)}$ （図 1)，得られた測定值は体格を考慮するため，身長で 正規化した。

理学療法初診時に評価項目として, Tr-AFD テスト, 胸郭拡張差, 日本整形外科学会肩関節疾患治療成績判定 基準（以下，JOA スコア），安静時抒よび運動時 Visual Analogue Scale (以下, VAS), 肩関節可動域 (屈曲, 下垂位外旋)，C7-TD を測定した。VAS の評価は, 横 $100 \mathrm{~mm}$ の直線が記載された紙面を渡し,「現在の(1)安 静時の肩関節痛, (2)運動時の肩関節痛はどの程度です か．０はまったく症状がない，100 は耐えられない痛み です。あてはまる程度に線を引いてください」という問 いに対し，対象者が自己記入した。

統計処理は, SPSS 14.0J for Windows（IBM 社製）を 使用し，Tr-AFD テスト抢よび胸郭拡張差と各評価項目 をSpearmanの相関係数にて算出し，有意水準は $5 \%$ と した.

\section{III. 結 果}

分析対象 22 名のそれぞれの平均值 \pm 標準偏差は, 患 側 Tr-AFD は $18.2 \pm 5.7 \mathrm{~cm}$, 身長で正規化した数值は $11.3 \pm 3.6 \%$, 健側 Tr-AFD $16.0 \pm 3.4 \mathrm{~cm}$, 身長で 正規化した数值は $9.6 \pm 2.2 \%, J O A$ スコアは $62.7 \pm 7.3$ 点, 安静時 VAS は $17.0 \pm 25.3 \mathrm{~mm}$, 運動時VASは $73.1 \pm 18.1 \mathrm{~mm}$, 屈曲は $114.0 \pm 21.8^{\circ}$, 下垂位外旋は $29.0 \pm 20.1^{\circ}$, 結带動作（C7-TD）は $43.7 \pm 10.2 \mathrm{~cm}$ で
表 1 対象者の基本属性と測定結果

\begin{tabular}{lc}
\hline 年齢 $($ 歳 $)$ & $57.0 \pm 11.1$ \\
性別 $($ 名 $)$ 男性 & 8 \\
女性 & 14 \\
身長 $(\mathrm{cm})$ & $161.1 \pm 8.9$ \\
体重 $(\mathrm{kg})$ & $60.3 \pm 11.5$ \\
$\mathrm{BMI}\left(\mathrm{kg} / \mathrm{m}^{2}\right)$ & $23.1 \pm 3.5$ \\
患側 $\mathrm{Tr}-\mathrm{AFD}(\%)$ & $11.3 \pm 3.6$ \\
健側 $\mathrm{Tr}-\mathrm{AFD}(\%)$ & $9.6 \pm 2.2$ \\
$\mathrm{JOA}$ スコア (点) & $62.7 \pm 7.3$ \\
安静時 VAS $(\mathrm{mm})$ & $17.0 \pm 25.3$ \\
運動時 VAS $(\mathrm{mm})$ & $73.1 \pm 18.1$ \\
屈曲 $(\circ)$ & $114.0 \pm 21.8$ \\
下垂位外旋 $(\circ)$ & $29.0 \pm 20.1$ \\
結帯動作 $(\mathrm{cm})$ & $43.7 \pm 10.2$ \\
\hline
\end{tabular}

$\mathrm{n}=22$. 平均值 \pm 標準偏差. BMI : Body Mass Index, Tr-AFD : Trunk-Acromion-Floor-Distance, JOA スコア：日本整形外科学会肩関節疾患治療 成績判定基準, VAS : Visual Analogue Scale.

あった（表 1）.

Tr-AFD テストおよび胸郭拡張差と各評価項目と相関 関係を認めたのは，患側 Tr-AFD テストと健側 Tr-AFD テスト : $\mathrm{r}=0.82(\mathrm{p}<0.01)$, 胸郭拡張差 : $r=-0.57$ $(\mathrm{p}<0.01)$, 安静時 VAS : $\mathrm{r}=0.50(\mathrm{p}<0.05)$, 健側 TrAFD テストと胸郭拡張差 : $\mathrm{r}=-0.45(\mathrm{p}<0.05)$, 安静 時 VAS : $\mathrm{r}=0.61 \quad(\mathrm{p}<0.01)$, 胸郭拡張差と安静時 VAS : $\mathrm{r}=-0.51(\mathrm{p}<0.05)$ であった（表 2$)$. 
表 2 Tr-AFD と各評価項目との相関係数

\begin{tabular}{|c|c|c|c|c|c|c|c|c|c|}
\hline & $\begin{array}{c}\text { 健側 } \\
\text { Tr-AFD }\end{array}$ & $\begin{array}{c}\text { 胸郭 } \\
\text { 拡張差 }\end{array}$ & 年齢 & JOA スコア & $\begin{array}{c}\text { 安静時 } \\
\text { VAS }\end{array}$ & $\begin{array}{c}\text { 肩運動時 } \\
\text { VAS }\end{array}$ & 屈曲 & 下垂位外旋 & 結帯動作 \\
\hline 患側 Tr-AFD & $0.82 * *$ & $-0.57 * *$ & -0.15 & 0.20 & $0.50 *$ & -0.42 & -0.13 & -0.25 & 0.14 \\
\hline 健側 Tr-AFD & & $-0.45^{*}$ & 0.01 & 0.14 & $0.61 * *$ & -0.31 & 0.09 & -0.28 & 0.01 \\
\hline 胸郭拡張差 & & & -0.08 & -0.07 & $-0.51^{*}$ & 0.28 & -0.05 & 0.06 & -0.30 \\
\hline 年齢 & & & & $0.42 *$ & 0.18 & -0.26 & 0.22 & 0.24 & $-0.44 *$ \\
\hline JOA スコア & & & & & 0.31 & $-0.57 * *$ & $0.64 * *$ & $0.63 * *$ & $-0.73 * *$ \\
\hline 安静時 VAS & & & & & & -0.15 & 0.19 & 0.03 & -0.12 \\
\hline 運動時 VAS & & & & & & & -0.33 & -0.13 & 0.25 \\
\hline 屈曲 ～～～～ & & & & & & & & $0.47 * *$ & $-0.54 * *$ \\
\hline 下垂位外旋 & & & & & & & & & $-0.72 * *$ \\
\hline
\end{tabular}

n=22. Tr-AFD：Trunk-Acromion-Floor-Distance, JOA スコア：日本整形外科学会肩関節疾患治療成績判定基準, VAS： Visual Analogue Scale. *: $\mathrm{p}<0.05, * *: \mathrm{p}<0.01$

\section{IV. 考 察}

肩関節周囲炎患者 22 名に対して, Tr-AFD テストと 胸郭拡張差を測定し，Tr-AFD テストと胸郭拡張差が関 連しているかについて調査した。 また, 胸郭可動性と肩 関節機能との関連についても検証した。

本研究の結果より，患側 Tr-AFD テストと胸郭拡張差, 健側 Tr-AFD テストと胸郭拡張差が負の相関関係を認め た。健常者に対するテープメジャーでの測定による胸郭 拡張差の信頼性は, 検者内信頼性が級内相関係数 (intraclass correlation coefficient : 以下, ICC) $=0.84$, 検者間信頼性が $\mathrm{ICC}=0.81$ と高い信頼性が報告されて いる16)。 また，我々が報告した健常者に対する Tr-AFD テストの信頼性においては, 検者内信頼性が $\operatorname{ICC}(1,1)$ $=0.80-0.92$ ， 検者間信頼性が $\operatorname{ICC}(2,1)=0.71-0.90^{14)}$ あり良好な信頼性であると考えられる.

鈴木ら 17) は, 健常者および高齢者において, 剣状突 起部での胸郭拡張差は肺活量と相関があると報告してい る。肺活量は, 肺および胸郭の大きさや弾性によって変 化することから, 剣状突起部での胸郭拡張差が胸郭可動 性を反映していることが考えられる．以上のことから， Tr-AFD テストは前胸部の可動性だけでなく, 胸郭全体 の可動性を反映していることが示唆される.

また，胸郭可動性と肩関節機能の関係においては，安 静時 VAS が患側 Tr-AFD テスト, 健側 Tr-AFD テスト, 胸郭拡張差と相関関係を認めた。 これらの結果から, 肩 関節周囲炎においては, 胸郭可動性が低いと肩の安静時 痛が強くなる傾向にある可能性が考えられる。

肩関節は肩甲上腕関節のみの運動ではなく, 胸郭を構 成する胸椎・肋骨・鎖骨・肩甲骨と連動して運動してい る. Hunterら 18) は, 肩インピンジメント症候群患者は 対照群と比較し, 胸椎伸展可動域が低下していることを 報告している。また Lawrence ら 19)は, 症候性肩群と
無症候群において, 肩甲胸郭の動きが肩の痛みに関連し ているか，鎖骨，肩甲骨，上腕骨にピンを挿入し，電磁 センサーにて解析する研究を行ったところ, 症候性肩群 が肩関節屈曲時に胸鎖関節の可動性が低下していること を報告している。篠田ら13) は，Tr-AFDテストは肩甲 胸郭関節, 肩鎖関節, 胸鎖関節, 胸郭の可動性が関与し それぞれを構成している勒帯, 関節包, 筋の柔軟性が影 響すると述べている，以上のことから，胸郭可動性が低 下すると肩関節への負荷が強くなり，何らかの障害が生 じ，肩の安静時痛へとつながる可能性が考えられる。

一方で，運動時 VAS は Tr-AFD テストおよび胸郭拡 張差と相関関係を認めなかった。 Hammond ら 20)は, 肩関節周囲炎のタイプ分類として, 肩運動機能に制限の あるものとないものに分けており，前者には癒着性関節 包炎, 変形性関節炎, 肩後方脱臼を, 後者には棘上筋腱 板炎，上腕二頭筋長頭腱炎などを挙げている。 そのため, 肩関節周囲炎のタイプにより，運動時痛の有無や痛みの 程度に差がでることが予測される。このことから，運動 時 VAS と胸郭可動性が相関関係を示さなかった可能性 が考えられる。

本研究結果より，肩関節周囲炎患者に対する治療およ び予防において, 胸郭機能の重要性が示唆され, 今後の 具体的な胸郭機能へのアプローチの検討につながると考 える。

本研究の限界として, 本研究は横断的調査であるため, Tr-AFD テストおよび胸郭拡張差と肩の安静時 VAS と の因果関係を示すことはできていない，また，対象者の 肩関節周囲炎における夕イプ分類や罹病期間を調査でき ていないこと, 症例数が少ないこと, 健常者との比較が できていないことが挙げられる。今後は症例数を増やし， 肩関節周囲炎のタイプ分類や罹病期間との関連, 健常者 との比較も含めて検討していきたい. 
利益相反 本研究に開示すべき利益相反はない.

謝辞 本研究の実施にあたり，ご協力を頂きました河内 総合病院リハビリテーション部の森英人先生, 坂本森先 生，松野諒平先生に厚く御礼申し上げます.

\section{引用文献}

1) Duplay ES: De la periarthrite scapulohumerale et des raideurs de l'epaule quien son la consequence. Arch Gen Med, 1872, 20: $513-542$.

2) 村木孝行: 肩関節周囲炎 理学療法診療ガイドライン. 理学 療法学, 2016, 43: 67-72.

3) Boyle-Walker KL, Gabard DL, Bietsch E, et al.: A profile of patients with adhesive capsulitis. J Hand Ther, 1997, 10: 222228.

4) Rauoof MA, Lone NA, Bhat BA, et al.: Etiological factors and clinical profile of adhesive capsulitis in patients seen at the rheumatology clinic of a tertiary care hospital in India. Saudi Med J, 2004, 25: 359-362.

5) Nobuhara K, Sugiyama D, Ikeda H, et al.: Contracture of the shoulder. Clin Orthop Relat Res, 1990, (254): 105-110.

6) Zuckerman JD, Rokito A: Frozen shoulder: a consensus definition. J Shoulder Elbow Surg, 2011, 20: 322-325.

7) 立原久義, 浜田純一郎：特発性凍結肩の 3 種類の夕イプと 治療的アプローチの違い. 関節外科, 2017, 36: 1062-1067.

8) 本橋恵美 : Joint by Joint Theory一関節別の主な機能から障 害の原因を探る一、臨床スポーツ医学, 2016, 33: 908-916.

9) Shōbo A, Kakizaki F: The relationship between thoracic configuration and changes in volumes of hemithoraces in upright sitting. J Phys Ther Sci, 2016, 28: 3205-3208.

10) Ueki J, De Bruin PF, Pride NB: In vivo assessment of dia- phragm contraction by ultrasound in normal subjects. Thorax, 1995, 50: 1157-1161.

11) 田平一行, 神津 玲, 千住英明：中高年者に扔ける胸郭拡 張差を加味した肺機能予測式の検討. 理学療法学, 1996, 23: 66-71.

12) 伊藤孝信, 福吉正樹, 永井教生 - 他 : 前胸部柔軟性低下と 投球障害の関連．東海スポーツ傷害研究会会誌，2012，30: $16-18$.

13) 篠田光俊, 赤羽根良和：肩甲帯機能に扔ける可動域制限の 要因について。整形外科リハビリテーション学会誌, 2015, 17: $37-42$.

14) 小坂健二, 越本浩章, 田中謙次・他：前胸部柔軟性テス卜 の検者内 ·検者間信頼性の検討. 理学療法科学, 2020, 35: 403-407.

15) Murrell GA, Walton JR: Diagnosis of rotator cuff tears. Lancet, 2001, 357: 769-770.

16) Bockenhauer SE, Chen H, Julliard KN, et al.: Measuring thoracic excursion: reliability of the cloth tape measure technique. J Am Osteopath Assoc, 2007, 107: 191-196.

17) 鈴木克昌, 高橋仁美, 菅原慶勇・他：肺機能予測としての 胸郭拡張差測定の有用性の検討. 日本呼吸ケア・リハビリテー ション学会誌, 2007, 17: 148-152.

18) Hunter DJ, Rivett DA, McKeirnan S, et al.: Relationship between shoulder impingement syndrome and thoracic posture. Phys Ther, 2020, 100: 677-686.

19) Lawrence RL, Braman JP, Laprade RF, et al.: Comparison of 3-dimensional shoulder complex kinematics in individuals with and without shoulder pain, part 1: sternoclavicular, acromioclavicular, and scapulothoracic joints. J Orthop Sports Phys Ther, 2014, 44: 636-645, A1-A8.

20) Hammond G, Torgerson WR, Dotter WE, et al.: The painful shoulder. Instr Course Lect, 1971, 28: 83-90. 